Copyright (C) 2021 by Cherkas Global University

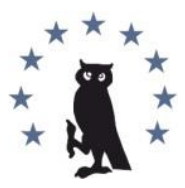

Published in the USA

Media Education (Mediaobrazovanie)

Has been issued since 2005

ISSN 1994-4160

E-ISSN 2729-8132

2021. 17(4): 723-730

DOI: $10.13187 / \mathrm{me} .2021 .4 .723$

https://me.cherkasgu.press

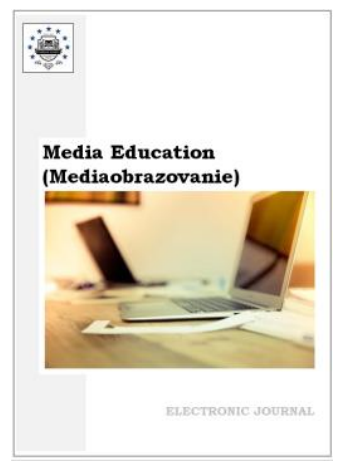

\title{
Oscar-winning Blockbuster Joker: Discovering the Layers of Philosophical Meaning
}

\author{
Inga Zashikhina a , *
}

a Northern (Arctic) Federal University named after M.V. Lomonosov, Russian Federation

\begin{abstract}
The American psychological thriller Joker made a lot of noise in the cultural world and became a blockbuster. The impact of the film was so huge that the images of the main hero Joker appeared in the most unexpected context. Joker could be the name of a café, teenager clothes shop, youth club, graffiti on the city building. It looked like the film produced multiple meanings for the audience and turned out to be one of those art objects that would stay as a part of the world culture. In this paper, we aim at analysing the meaning-constructing images that comprise the content matrix of the film Joker. For this, we firstly consider the contemporary cinematic theory and point out the ideas of the acknowledged experts and thinkers that are significant for film analysis. Then we approach the studies of prominent researchers of culture and philosophy that are critical for the film understanding. We also engage in hermeneutic analysis to follow the events and characters of the film plot. The final purpose of the research is to draw a resume that would define the philosophical value of the American blockbuster and explain its multi-layered sense for the world audience.
\end{abstract}

Keywords: Joker, evil clown, batman, film, cinema, philosophy, multi-layered meaning, analysis, comedy, tragedy.

\section{Introduction}

One of the first scholars who paid attention to the philosophical value of cinema was G. Deleuze, the author of "Cinema" in two volumes (Loyo, 2018). G. Deleuze believed that cinema is a special organism to which we entrust our perception, our subjectivity. Cinema approaches such phenomena as sleep, madness, hallucinations, and defies rational explanation. It is also due to cinema that we get an invaluable experience that is inaccessible to us in real life. At the very least, cinema is the means that allows us to see the complexity of our life with its interminable quantity of choices, solutions, connections, and possibilities.

Other social thinkers - S. Cavell, S. Mulhall, R. Sinnerbrink have argued that film can be philosophy (Cavell, 2005; Mulhall, 2002; Sinnerbrink, 2014). From cinema, philosophy can learn to speak directly to the human heart. Films may have the same effect as great philosophical works. They shake, breathe new life into our minds, open up new opportunities to see ourselves and the world around us. Film viewers are driven by emotion and passion as well as by reason. Mythical imagination plays the same role as argumentative thinking. The depth of vision and the quality of understanding equal the works of A. Tarkovsky, I. Bergman and A. Kurosawa to the works of great philosophers.

Contemporary philosophy conveys its meanings primarily through a text. Cinema does the same via dynamic images. Philosophy addresses the human mind; cinema reaches the human

\footnotetext{
${ }^{*}$ Corresponding author

E-mail addresses: i.zashikhina@narfu.ru (I. Zashikhina)
} 
heart. While philosophy demands reflection, cinema seeks an experience. Philosophy requires logical thinking, cinema asks for emotional empathy. Above all, cinema acts through emotions, through feelings. A film may contain a few words, mostly images and music. It is a synthetic art that combines words, images, dynamics and music (Tan, 2018).

There are good films and not so good films. Some films are more sophisticated, others rather primitive. Separate critics claim that modern cinema is getting less and less worthwhile (Van de Vijver, 2017). However, contemporary world cinematography can boast of such composite films which manifest sheer philosophy. Among them are, for example, Irrational Man by W. Allen and Forrest Gump by R. Zemeckis. Russian films by A. Tarkovsky, S. Eisenstein, A. Sokurov, A. Zvyagintsev, A. Konchalovsky call for reflection and reassessment of personal experience. In this paper, we are going to contemplate the philosophical depth of the American deep and rich in implications film - Joker, directed by T. Phillips. Our aim is to reveal the conceptual layers of meaning that make the understanding of the film fuller.

\section{Materials and methods}

This article attempts at philosophical analysis of Joker film by T. Phillips, released in 2019. To assure an easy understanding of the analysed material, first, we provide a brief overview of the film's content concentrating on the flow of the events. Then we proceed with the main aim of the study and move in two interrelated directions. On the one hand, we cogitate on the contemporary cinematic theory and point out the ideas of the acknowledged experts and thinkers that are significant for film analysis (Eco, Barthes, Herzogenrath, Bazin, Kurennoy). On the other hand, we approach the studies of prominent researchers of culture and philosophy that are critical for Joker understanding (Camus, Schopenhauer, Nietzsche, Freud, Foucault, Zizek, Radford). On the metalevel, for the analysis of Joker film, we resort to the hermeneutic method as one of the most recognized methods for media analysis (Chelysheva, Mikhaleva, 2018; Fedorov et al., 2018).

Blockbuster Joker as a complex representation of contemporary social artefacts

Joker is an American psychological thriller, directed by Todd Phillips. Some cinema critics define it as social horror (Semlyen, 2019). The script is written by Phillips in collaboration with Scott Silver. Actor Joaquin Phoenix plays the main role, Joker. The plot of the picture is a version of the backstory of the supervillain Joker, one of the key antagonists of Batman in the comics of DC Comics. The film was based on the comic Batman: The Killing Joke, however, according to Phillips and Silver, the script does not copy it. Filming took place in New York, Jersey City and Newark from September to December 2018. Joker is the first Batman movie to receive an $\mathrm{R}$ rating due to its violent scenes. R-rated films contain material intended only for an adult audience. The Motion Picture Association of America rated Joker R for strong bloody violence, disturbing behaviour, language and brief sexual images. Parents are encouraged to think carefully before watching such a movie with their children.

The film is set in 1981 in Gotham. The main character is rejected by society Arthur Fleck. Arthur lives with his sick mother Penny. He works as a clown in a small entertainment agency and dreams of becoming a stand-up comedian. His idol is the popular TV showman Murray Franklin, whose evening show Arthur and his mother watch every day. In addition, Arthur suffers from a neurological disorder that makes him laugh in tense situations. To suppress these attacks, Arthur has to take powerful drugs from a social worker.

After a gang of bullies attack him in the street, Arthur gets a revolver from his colleague Randall as a means of self-defence. During a performance at the Children's Hospital, Arthur's revolver accidentally falls out of his pocket in front of the spectators. The agency finds this out and Arthur is fired. Treacherous Randall lies to his bosses that Arthur tried to buy weapons from him.

In the subway, still wearing the clown's makeup, the main character witnesses three drunken men to molest a girl. Arthur breaks into a sudden burst of laughter, which draws the molesters' attention. The latter begin to scoff and beat Arthur. As a result, Fleck cannot stand it, pulls out a revolver and kills all the three men.

Gotham's mayoral candidate, billionaire Thomas Wayne, condemns this crime. It turns out that those killed were the managers of his corporation. Wayne calls those who are jealous of more successful people clowns, and his words lead to massive protests in the city. Protesters put on clown masks in approval of Arthur. Meanwhile, due to the crisis, the city is cutting funding for welfare programs, leaving Arthur without the medication he needs. 
Arthur's mother Penny suffers a stroke and is admitted to the city hospital. At that time Arthur learns that he had been adopted by his mother and her roommate used to beat the boy brutally, which resulted in Arthur's serious head injury. Standing by the side of his mother's bed, Fleck takes her pillow and uses it to smother the woman to death. "She always tells me to smile and put on a happy face. She says I was put here to spread joy and laughter," - says Arthur.

Joker philosophises:

Hm? You know what I noticed? Nobody panics when things go "according to plan". Even if the plan is horrifying. If tomorrow I tell the press that, like, a gangbanger will get shot or a truckload of soldiers will be blowing up nobody panics. Because it's all part of the plan. But when I say that one little old mayor will die well, then, everyone loses their minds. Introduce a little anarchy, upset the established orders and everything becomes chaos. I'm an agent of chaos. Oh, and you know the thing about chaos? It's fair.

\section{Discussion}

Transfer of meanings in cinema

In his book Film and/as Philosophy: An Elective Affinity?, editor of the book B. Herzogenrath proposes looking at the film as philosophy (Loyo, 2018). Such a perspective treats films as venues for reflection, not just illustrations of events and ideas. Philosophy and film come as two interrelated areas. The role of a viewer changes from an interpreter of representational techniques of a film director to an active thinker finding alternative thoughts and logics (Coëgnarts, 2017). Film watching turns into an enriching encounter with the director's original point of view. Using the mechanisms of contextual analysis and cinema semiotics is not a part and parcel of filmwatching. However, the ability to distinguish significant meaning components gives a viewer a new level of heuristic power (Salny, 2019; Shuneyko, Chibisova, 2019).

U. Eco developed his theory of cinema semiotics, where he presented the idea of a three-part cinematic code that makes messages of a film different from other types of messages (Volli, 2021). Eco claimed, semiology is very important for the interpretation of our world (Eco, 1976). Semiology is capable of revealing ideologies, hidden in the universe of signs, with the help of codes and subcodes. Semiology explains the world of cinema with triple articulations codes consisting of figures, signs and elements, makes the cinema world itself a richer form of communication than speech. Remarkably, much depends on the interpreter, i.e. film viewer. When a viewer watches a film, they notice the figures, signs and elements that the film director does not take into the focus or does not show in the film altogether. Examples of such may be the connotations tied to the film image, social status of the film hero, event or attitude. The appearance of connotative meanings, which are optional and differ from one viewer to the other, add complexity and depth to the film.

V. Kurennoy speaks of cinema as the most social kind of art, implying large masses of society involved in both film production and film consumption (Kurennoy, 2009: 11). Finances, necessary for filmmaking, make producers careful in their choices. A created film should be attractive and understandable for the audience (Tan, 2018). Familiarity, making a film accessible and interesting, means that a film viewer will see the characters and events as comprising facts of the viewer's life (Semetsky, 2018). We only notice those ideas that we have already come across in our experience, even imperceptibly. In this respect, a popular film scenario has to present a story that consists of phenomena important for the target audience. Thus, the plot needs to include recognizable and approved patterns of behaviour, forms of social conflicts and norms, life goals, etc., turning the imaginary film, to a certain extent, into the reflection of real life through the lens of the filmmakers.

R. Barthes, one of the pioneers of the semiotic study of cinema, proceeds from the prerogative of the signifying over the signified. To transmit the message, the author and viewer must have access to the cultural code. Barthes writes: "The search for signs is carried out within strictly defined boundaries, which cannot be exceeded - otherwise the film will be incomprehensible. However, within these borders, the reserves of signs are very mobile: the author can draw the strength of his messages in a common, traditionally established dictionary of cinema signs ... or the same in the symbolism of a universal type, perceived more or less unconsciously" (Barthes, 2004: 358).

Referring to the characteristics of the cinematic signified, Barthes comes to the conclusion that cinematography is unable to fully comply with the function of transferring meanings (Konstantinov, 2019). The scholar expresses scepticism towards the communicative possibilities of cinema. In his opinion, in a film, the signified is episodic, discreet, and often marginal (Barthes, 
2004: 364). It is only a part of the film content that produces meanings. The rest of the content reproduces the obvious. The high value of a film lies in its ability to represent what is not shown. It can be references to an image, social status, event, state, or attitude.

Literature makes an essential referential system for the cinema. When a viewer watches a film, their mind is referred to literature. Film's content is not only images but includes narratives. In this meaning, a film's narrative is a literary work. These are intellectual narratives from philosophy, sociology, political manifests, etc. Just like a literary work has several layers which have different intellectual depth, a film also allows for infinite modes of perception, depending on the audience's background. Nevertheless, there is a certain difference between a literary work and a feature film. A literary narrative grants its reader a chance to imagine, construct and add to the text, building a character or event in their nuances. As for the film, its plot and heroes are thought through by its creators and give fewer opportunities for imagination.

However, a film is capable of producing a huge effect on its viewer. Its impact is built on a number of senses, that are employed in the course of film watching: eye vision, hearing and conscience. Sensitivity, characteristic of the human brain, is a minimum guarantee of the artistic potential of cinema. The maximum film influence is not limited but relies on the individual experience of contextual narratives accessible to the viewer. Among such contexts are historical, political, technology-related, actors-related narratives. In this respect, the film is a subject for interminable interpretations (Kurennoy, 2009: 29). The immersive nature of the modern film exploits the audience's emotions and kinesthetic means of film's consumption. The effect of presence, easily produced by the breakthrough technologies, draws the audience into the world of film reality. The latter is not necessarily representative of real life. The reality created by film producers is deeper. It is multilayered.

Distinguished cinema critic A. Bazen noted that the duplication of reality in a film is coupled with the aesthetic-symbolic-expressive rendering of things as meaningful to human subjects. Bazen states that in a film, the representation of life is better accomplished stylistically by means of invisible montage, which involves the creation of a sense or meaning not objectively contained in the images themselves but derived exclusively from their juxtaposition (Bazen, 1972). Through mental montage, the meaning is generated intellectually or associatively, rather than derived from the juxtaposed images themselves. In this respect, to get the most of a film in the intellectual sense it is vital for the viewer to relate the images from the screen to the cultural massive of connected images.

Layers of meaning in Joker film

Expressing his admiration to T. Phillips, director of Joker, S. Zizek points out the fact that the film popularity builds on its meta-functional dimension (Zizek, 2019). The plot is the genesis of the Batman story. Batman is a superhero of American comic books, who first appeared in 1939 (Bal et al., 2013). Batman is the nickname of Bruce Wayne, a wealthy American playboy, philanthropist, and industrialist, living in Gotham City. The comic book's character becomes a witness of his parents' murder and start shis nemesis, killing Gotham criminals. Batman trains himself physically and intellectually, creates a bat-inspired persona and follows a stringent moral code and a strong sense of justice. Zizek notes, that without the reference to Batman character, residing in the city with the same name, Gotham, a victimized child and unsuccessful stand-up comedian Arthur Fleck would not reach such an effect. The multi-layered image of a clown surviving his predicament, that dwells in media culture and history, turns Joker into a social horror film.

Another image that added to the success of Joker is Pennywise from It by renowned S. King (King, 2016). Pennywise or It is an all-encompassing evil of various shapes and sizes that appears every 27 years in Derry, Maine. Its main goal is to kill children. To reach the aim Pennywise exploits the mask of becoming an attractive clown. The monster chose the face of a funny clown because it makes it easier to lure children. It uses fear as a seasoning. According to him, the meat of half-dead from terror victims is much tastier. In fact, It is far from being a clown. This is a werewolf, a shape-shifter, who knows how to take any form and control consciousness. The evil monster covers under the deceitful appearance of a clown just like Arthur Fleck hides his nature behind a clown mask.

The evil clown phenomenon is also a critical content component, adding to the perception of Joker character. The very concept of evil has been employed in social research as a developing and creative force (Black et al., 2018; Varga, 2019). The tradition of an evil clown was launched at the beginning of the 19th century by the British pantomime actor Grimaldi (Macdonald, 2016). The latter presented a whiteface character Joe with vivid hair and a multi-colour costume that can 
be considered a predecessor of the modern malicious clown. It behaved menacingly and was unsettling yet amusing.

In his book Bad Clowns, a well-known folklorist Benjamin Radford presents the history of the cultural phenomenon of a bad clown, who terrorized, haunted, and threatened their audience. In this resource, the scholar contemplates the origins of the creepy image and argues, that the notion of clowns as good is fairly modern (Radford, 2016). In fact, early clowns already were at least mischievous but normally socially marginal, sinister and scary. The fear of clowns is not so straightforward and intricate for explaining. Clown's harm is hidden in their funny and silly appearance.

In the 1989 film Batman Jack Nicholson's joker utters a question: “Tell me, my friend, have you ever danced with the devil in the pale moonlight?"(Burton, 1989). The image of a clown in the dark night is different from a clown on the circus ring. When a clown gets out of his professional arena into the world of common people, the produced effect turns from playful to terrifying. The effect even doubles if we face a grotesque, weird-looking clown in the darkness tet-a-tet. The feeling of paranormal, of existing silver lining, makes us expectant and suspicious. This expectation is grounded in the clown's ambiguity of a miserable, half-mad showman, prone to depression, whose mission is to make people laugh. "The clown lives in the place of laughing and crying at the same time... It is an embodiment of hope in the face of hopelessness, and possibility in the face of the impossible" (Henderson, 2021).

Philosophical theories and concepts developed by acknowledged thinkers provide another stratum of interpretation for understanding Joker. Thus, discussing his comedy through tragedy concept, A. Schopenhauer wrote: "The life of every individual, viewed as a whole and in general, and when only its most significant features are emphasized, is really a tragedy; but gone through in detail it has the character of a comedy" (Schopenhauer, 2012: 322). In his turn, Arthur Fleck utters: "I used to think that my life was a tragedy, but now I realize, it's a comedy". The phrase marks a borderline when the main character of the film realizes the adversity of his situation. It is also the climax of the plot. From that moment on Joker acts as an agent, not a passive receiver of life's pain and sorrow.

In M. Foucault's Madness and Civilization: a History of Insanity in the Age of Reason, madness is described as not a natural, unchanging phenomenon but rather dependable on the society where it exists (Foucault, 2001). Foucault's work explains how the mad came to be confined. People with a psychiatric predicament become identified as confined due to moral and economic factors that are defined by those in the position of power. The mad are perceived as dangerous through their confinement and remain confined in asylums and in the stigma of being mad (Longhurst, 2017). The film plot is a direct illustration of Foucault's theory. The society is really cruel towards Joker's disease. However, Joker outcries: "Is it me or the whole world is going mad?". The juxtaposition of a confined clown and his perception of this confinement is what Foucault spoke about decades ago.

In Camus' theories of absurdity and rebel, Arthur Fleck would fit as an absurd hero. Philosopher described human longing for happiness and life meaning as absurd and unattainable in the conditions of the cold and harsh real world (Pölzler, 2018). Absurd hero recognizes the absurdity of the human condition. Moreover, Camus' absurd hero embraces the struggle of living life meaninglessly-yet contently-in our storming, jumbled world. The only thing that can break through the viscous veil of any absurdity is a human deed (Camus, 1991). It is only important that it be genuine, and a genuine act is always performed for the sake of the act itself - without a goal, without justification, without hope to change something. Joker's rebel and shooting acts are examples of human deeds in Camus' sense. The violence of Joker is obviously legitimized in the eyes of Gotham citizens due to its genuineness. Although Arthur represents an extreme form of Absurdism through the acts of murder and inciting anarchy, the philosophy woven into the character's very fabric nonetheless speaks to audiences who, at some point, have felt the gravitas of an absurd reality (Narciso, 2019).

Freudian theory of psychoanalysis might provide quite a detailed study of the roots of Fleck's behaviour. According to Freud, an individual is derived by their unconscious mind (Lepoutre, 2020). Childhood abuse and lack of parental love have an immense impact on human personality. Traumatic events that happened in childhood set off a series of recollections in the child's mind. Delayed recognition becomes a pathogenic idea that is potential of hysteria and pathological conditions in adulthood (Freud, 2017). Thus, Arthur's head trauma and childhood injuries lead to the conditions he faced as an adult. Being a caring son, in the end, Arthur kills his mother as the 
one responsible for his mental state. At this point, we recall that Freudian psychoanalysis in K. Jung's version employs the metaphor of a shadow. Shadow is the part of a person's psyche they do not admit. This phenomenon makes us desire the boss's death or friend's failure. "The Joker is simply an outlet for the Shadow... He acts in ways that we sometimes wish we could, deep down, and we get a vicarious rush out of seeing him indulge in such behaviour, without anyone really getting hurt" (Vats, 2017).

Nietzsche's nihilism theory answers the question of why Arthur Fleck is so categorical in his expression. German philosopher F. Nietzsche describes nihilism as the state when "... any aim is lacking, any answer to the question "why" is lacking" (Nietzsche, 2019: 327). To Nietzsche, the existence of such nihilistic ideology is a very dangerous phenomenon to society, as a whole. A nihilist is someone who does not have personal beliefs in any moral codes or valuesand also acts to encourage others to do the same (Toribio Vazquez, 2020). Joker demonstrates a dark and gloomy voyage into a nihilistic state of mind. Arthur endlessly questions his own existence. He does not find any meaning in his life. Moreover, Joker experiences problems acknowledging his own being. His permanent negative thoughts bother him to the point of mental torture. Arthur notes in his journal: "I just hope my death makes more cents than my life" (Joker, 2019, [06:20]). This is the extent of how empty and worthless he finds his life. While the conditions are getting tougher every day, Arthur does not meet anyone ready to help and soon feels utterly desperate, reaching the ultimate phase of nihilism (Sayed, 2019). "Paraphrasing Nietzsche, we might say that whoever fights monsters will surely become a monster" (Bolea, 2019).

\section{Results}

In this study, we produced a philosophical analysis of the film Joker by T. Phillips. Our aim was to reveal the depth of contextual meanings that made Joker a blockbuster. The result of our search may be expressed in a form of the following resume.

Human society does not welcome otherness in people. It more readily stigmatizes those who are different from the rest. Tolerance, in this respect, is still a matter of theoretical slogans, subjected to hypocrisy. The absence of sympathy towards social outcasts is especially explicit when a person suffers from a psychiatric disease. Even more appalling is the fact that the state government is not ready to take the responsibility for the psychiatric patents either. In the conditions of neoliberal capitalism, the diseased become critically vulnerable and present a threat to both themselves and society. Decreased financial support for medical institutions inflates the problem to an insurmountable extent. When this happens, there is no opportunity to speak of peaceful means of regulating conflicts. The streets of Gotham city turn into a battlefield. Everyone gets involved in the war between good and evil, tolerant and intolerant, the rich and the poor, the powerful and the powerless. When the clash is so massive, it is hard to differentiate between victims and exploiters. When there are no sane and strong leaders capable of solving such a mammoth existential conflict, the world seeks a prodigy. In the Joker film it is Arthur Fleck who comes as a unifying force and a symbol of liberation. It looks like violence is the only way out in the fight with class inequality and state indifference. Paradoxically, serenity and balance do not work for coping with the evils of the late-era capitalism. The surreal figure of a clown operates against normative ways of succeeding. The exposed indifference to the prevailing norms allows a clown to solve the problem, even if the solution is contrary to what is expected by the social mainstream.

\section{Conclusion}

This study attempted at the interpretation of the complex ideas that allowed Joker film to become so warmly received by the world audience. Such an analysis demanded attention to the modern theory of cinema in the part that is related to the production of meaning in a feature film. The encounter with cinematic theory showed that the content of a high-level modern feature film is a subject of multiple connotations. The connotations come from various sources and first of all, depending upon the viewer's background experience, both cultural and philosophical. The other factors that add to the fullness of expression may relate to the sensitive capacity of the audience. While the last is totally subjective matter, cultural and philosophical ideas are the area that can be tracked by an attentive and reflecting viewer. In this research, we tried to take on the relevant attitude and look at the events that could impact our impressions of the film. The findings are presented in a form of a philosophical resume. We must observe that the produced analysis is far 
from being ultimate. New images occur in relevance to individual life experience and the interpretation can definitely be prolonged. The highly relevant and meaningful plot, well-chosen acting cast, artistic means used by the film directors made the Joker film a remarkable resource for thinking that can be used to discuss acute social philosophical problems of modernity.

\section{Acknowledgement}

I would like to express my appreciation to the students of Liberal Arts direction who study at Northern (Arctic) Federal University and take part in the philosophical discussions on various topics, Joker film has been one of them. In the course of our conversations, they articulated many valuable ideas and asked questions that prompted the author of this text to seek resources, which became the base of the research.

\section{References}

Artamonova, 2020 - Artamonova, U. (2020). Amerikanskii kinematograf kak instrument publichnoj diplomatii. Analiz I prognoz [American Cinematography as a Tool of US Public Diplomacy. Analysis and forecast]. Journal of IMEMO RAN. 2: 110-122. [in Russian]

Bal et al., 2013 - Bal, Z.E., Dikencik, M.C. (2013). The Dark Knight and the Ideology Behind. Procedia - Social and Behavioral Sciences. 82: 580-584. DOI: 10.1016/j.sbspro.2013.06.313

Barthes, 2005 - Barthes, R. (2004). Problema znacheniya v kino. Sistema mody. Stat'i po semiotike kul'tury [The problem of meaning in cinema. Fashion system. Articles on the semiotics of culture]. Moscow. [in Russian]

Bazen, 1972 - Bazen, A. (1972). Chto takoe kino [What is Cinema]. Moscow. [in Russian]

Black et al., 2018 - Black, J.E., Helmy, Y., Robson, O., Barnes, J.L. (2018). Who can resist a villain? Morality, Machiavellianism, imaginative resistance and liking for dark fictional characters. Poetics. DOI:10.1016/j.poetic.2018.12.005

Bolea, 2019 - Bolea, S. (2019). Joker. Philosophy Now. [Electronic resource]. URL: https://philosophynow.org/issues/136/Joker

Burton, 1989 - Burton, T. (1989). Batman film. [Electronic resource]. URL: https://www.kinopoisk.ru/film/4205/

Camus, 1991 - Camus, A. (1991). The Rebel. An essay on man in revolt. NY: Vintage Books. $310 \mathrm{p}$.

Camus, 1991 - Camus, A. (1991).The Myth of sisyphus and other essays. NY: Vintage Books. $212 \mathrm{p}$.

Cavell, 2005 - Cavell, S. (2005). Cavell on Film. NY: State University of New York Press. 400 p.

Chelysheva, Mikhaleva, 2018 - Chelysheva I., Mikhaleva G. (2018). Hermeneutical analysis of feature films of English-speaking countries about university students. Media Education. 58(3): 24-31.

Coëgnarts, 2017 - Coëgnarts, M. (2017). Cinema and the embodied mind: metaphor and simulation in understanding meaning in films. Palgrave Commun. 3:17067. DOI: 10.1057/ palcomms.2017.67

Eco, 1976 - Eco, U. (1976). Movies and methods: an anthology. Vol. 2. Berkeley: University of California Press. 635 p.

Esraa, 2019 - Esraa S. (2019). Political and philosophical analysis for "Joker" Movie. DOI: 10.13140/RG.2.2.19399.85921

Fedorov et al., 2018 - Fedorov, A., Levitskaya, A., Gorbatkova, O., Mikhaleva, G. (2018). Professional risk: sex, lies, and violence in the films about teachers. European Journal of Contemporary Education. 7(2): 291-331. DOI: 10.13187/ejced.2018.2.291

Foucault, 2001 - Foucault, M. (1965). Madness and Civilization: History of insanity in the age of reason. NY: Random House. 317 p.

Freud, 2017 - Freud, Z (2016). Studies on Hysteria. Create Space Independent Publishing Platform. 254 p.

Henderson, 2021 - Henderson, J. (2021). Clown Philosophy. [Electronic resource]. URL: https://www.foolmoon.org/clown-philosophy

Khalilov, 2019 - Khalilov, V. (2019). Sovremennoe amerikanskoe kino I neoliberal'naya ideologiya [Contemporary American cinema and neoliberal ideology]. USA \& Canada: Economics - Politics - Culture. 2: 112-127. [in Russian]

King,2016 - King, S. (2016). It. NY: Scribner. 1143 p. 
Konstantinov, 2019 - Konstantinov, M. (2019). Roland Barthes and Yurii Lotman - search for meaning in film narrative. Chapter in Bulletin of Kyiv National University of Culture and Arts Series in Musical Art. DOI: 10.1314O/RG.2.2.21800.19203

Kurennoy, 2009 - Kurennoy, V. (2009).FIlosofiya fil'ma. Uprazhneniya v analize [Philosophy of film: Exercises in analysis]. Moscow. [in Russian]

Lepoutre et al., 2020 - Lepoutre, T., Fernandez, I., Chevalier, F., Lenormand, M., Guérin, N. (2020). The Psychoanalytical boundaries of the ego: Freud, Klein, Winnicott, Lacan. L'Évolution Psychiatrique. DOI: 10.1016/j.evopsy.2020.08.0

Longhurst, 2017 - Longhurst, $P$. (2017). Madness and the material environment: an archaeology of reform in and of the asylum. International Journal of Historical Archaeology. 21(4): 848-866. DOI:10.1007/s10761-017-0399-0

Loyo, 2018 - Loyo, H. (2018). Bernd Herzogenrath, ed. Film as Philosophy. European journal of American studies, Reviews. 2. [Electronic resource]. URL: https://journals.open edition.org/ejas/13263?lang=en

Macdonald, 2016 - Macdonald, F. (2016). A Surprising history of the creepy clown. [Electronic resource]. URL: https://www.bbc.com/culture/article/20161019-a-surprising-historyof-the-bad-clown

Mulhall, 2002 - Mulhall, S. (2002). On Film. NY: Routledge. 142 p.

Narciso, 2019 - Narciso, J. (2019). Understanding the Joker: a philosophical diagnosis. [Electronic resource]. URL: https://www.thebubble.org.uk/culture/philosophy-religion/under standing-the-joker-a-philosophical-diagnosis/

Nietzsche, 2008 - Nietzsche, F.W. (2008). Thus Spoke Zarathustra. Oxford: Oxford University Press. 384 p.

Nietzsche, 2019 - Nietzsche, F.W. (2019). The Will to Power. Trans. Walter Kaufmann. NY: Dover Publications. 240 p.

Pölzler, 2018 - Pölzle, T. (2018). Camus' feeling of the absurd. The Journal of Value Inquiry. DOI: 10.1007/s10790-018-9633-1

Radford, 2016 - Radford, B. (2016). Bad Clowns. Ch. 3. Albuquerque: University of New Mexico Press. 216 p.

Salny, 2019 - Salny, $R$. (2019). The role of ontological time forms in film appreciation. Media Education. 59(1): 116-122.

Schopenhauer, 2012 - Schopenhauer, A. (2012). The World as Will and Representation. Vol.1. NY: Courier Corporation, 696 p.

Semetsky, 2019 - Semetsky, I. (2019). Visual semiotics and real events. Video Journal of Education and Pedagogy. 4(2): 90-110. DOI: 10.1163/23644583-00401006

Semlyen, 2019 - Semlyen, P. (2019). Joker. Time out Says. [Electronic resource]. URL: https://www.timeout.com/movies/joker-1

Shuneyko, Chibisova, 2019 - Shuneyko, A, Chibisova, O. (2019). The mechanism of contextual confirmation of the symbol in the cinema language. Media Education. 59(1): 123-134.

Sinnerbrink, 2014 - Sinnerbrink, $R$. (2014). Cavellian Meditations: How to do Things with Film and Philosophy. Film-Philosophy. 18: 50-69.

Tan, 2018 - Tan, E. (2018). A psychology of the film. Palgrave Communications. 4(1).

Toribio Vazquez, 2020- Toribio Vazquez, J.L. (2020). Nietzsche's shadow: On the origin and development of the term nihilism. Philosophy \& Social Criticism: 019145372097545. DOI: 10.1177/0191453720975454

Van de Vijver, 2017 - Van de Vijver, L. (2017). The cinema is dead, long live the cinema! Understanding the social experience of cinema-going today. Participations. 14(1): 129-144.

Varga, 2019 - Varga, B.A. (2019). Book Review. The Journal of Social Studies Research. 43(4): 431-433. DOI: 10.1016/j.jssr.2019.09.001.

Vats, 2017 - Vats, A. (2017). Understanding Joker: a psychological view. [Electronic resource].

URL: https://medium.com/@adityavats/understanding-joker-a-psychological-view-9oda73bfd557.

Volli, 2021 - Volli, U. (2021). The origins of Umberto Eco's semio-philosophical project. Rivista di estetica. 76: 81-95.

Zizek, 2019 - Zizek, S. (2019). More on Joker: from apolitical nihilism to a new left, or why trump is no Joker. [Electronic resource]. URL: http://thephilosophicalsalon.com/more-on-jokerfrom-apolitical-nihilism-to-a-new-left-or-why-trump-is-no-joker/ 